$\left.\left.11^{-13}\right|_{\text {LA }}\right|^{9}-5281-M S$

INFORMAL REPORT

$3^{3}$

\title{
Transuranic Waste \\ Research and Development Program
}

THIS DOCUMENT CONFIRMEO AS.

UNCLASSIFIED

DIVISION OF CLASSIFICATION

DATE Lisucd hiara fuer

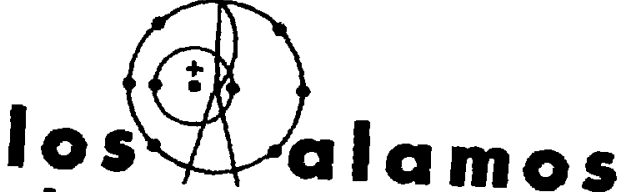

scientific laboratory

of the University of Colifornia

LOS ALAMOS, NEW MEXICO 87544

1

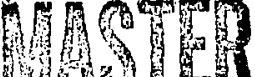

政的的

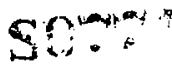


In the interest of prompt distribution, this LAMS report was not edited by the Technical Information staff.

Printed in the United States of America. Available from National Technical Information Service

U. S. Department of Commerce

\section{Port Royal Road}

Springfield, Virginia 22151

Price: Printed Copy $\$ 00$; Microfiche $\$ 0.95$

$\times 4.00$ 
LA-5281-MS

INFORMAL REPORT

UC. 70

ISSUED: May 1973

\title{
Transuranic Waste Research and Development Program
}

by

\author{
E. B. Fowler \\ J. L. Warren \\ K. A. Pashman \\ J. W. Healy
}

This report was NOTICE

sponsored by the prepared as an account of work

the United States nor the United Government. Neither

Comminsion, nor any of their ertates Atomic Enery their contractora, subcontractors, employees, nor any of mukes any warranty, expreas or implot their employees, lezal lisbility or responsibility for the or astumes any pletenest or usefuness of would or process discloetny information, apparetus, would not infringe privetely owned represents that fts we

This work supported by the U.S. Atomic Energy Commission's Division of Waste Management and Transportation 
TRANSURAINIC WASTE RESEARCH AND DEVELOPMENT PROGRAM

by

The Staff of LASL Health Division

with

Contributions from CMB Division and $A$ Division

\begin{abstract}
This report reviews the progress of the Transuranic Waste Research and Development Program at the Los Alamos Scientific Iaboratory for the period November 1, 1972 - March 1, 1973. The results of a survey of transuranic waste streams and waste management practices at six major AEC installations indicated the wide variety of wastes and waste handling practices in existence and the need for some uniformity in record keeping. preliminary results of experimental studies of corrosion sources and mechanisms using $17 \mathrm{C} 55-$ gallon drums suggest that unrelieved stress may be a major contributor to the corrosion of the drum. Combugtion studies of typical waste types demonstrated the production of large quantities of smoke and gases but failed to produce a flame at temperatures up to $450^{\circ} \mathrm{C}$. Leaching studies showed that plutonium is removed from the wastes by water at a rate that decreases after the first few hours of contact. progress on the development of an assay system to detect radioactive contaminants in very low concentrations in waste is reported.
\end{abstract}

\section{INTRODUCTION}

The Transuranic Waste Research and Development Program continued during this period with the effort directed toward the twenty year retrievable storage of solid wastes generated at $\mathrm{AEC}$ production and $1 \mathrm{ab}-$ oratory sites. A survey of the major waste generators and storage sites at AEC locations was initiated to better characterize the waste types and current waste management practices : this information is being used to provide a background for the writing of general criteria to be used as goals for the design of specific systems of waste handling and storage. Later, it will serve as a basis for studies of the optimization of overall waste management proceduxes.
The experimental program continued its emphasis on defining general mechanisms which could pose a threat to the integrity of the packaging and on obtaining data needed to assess the risks associated with handling and storage. Such studies are, by their very nature, long term since they must consider and identify events which can take place over an extended period of time. The cooperative nature of the program with other Divisions in the Laboratory continued, the experimental phases being conducted by both CAB and $A$ Divisjons, with H-Division providing the overall management and analysis of the information. The effort on calculation of radiation dose. self-heating, and criticality was terminated at the middle of the period due to 
the change in program emphasis toward AECgenerated wastes and short-term storage.

The effort at the end of the period was divided as follows:

Group H-7 (Industrial Waste) - two full-time staff members, one part-time staff member, and one graded series working on the analysis of information and the overall program management. In addition, one staff member is employed full-time on the clesely associated Waste volume Reduction Facility Program.

Group CMB-1 (Chemistry, Material science, Analytical) - one full-time staff member and two graded series performing analytical chemistry and laboratory studies leading to information on potential release mechanisms and the risks involved if contamination is released.

Group CMB-11 (Chemistry, Material Science, Plutonium) - one full-time staff member and two graded series performing field tests on mechanisms of release and the associated risks. In addition, they are working closely on the waste survey and on the considerations of criteria development.

Group A-1 (Assay and Accountability. Nuclear Materials) - one staff member working on the measurement of contamination levels in waste at the $10 \mathrm{nCi} / \mathrm{g}$ level using the general approach outlined in the last report of this program. ${ }^{I}$ at the end of this period, it was decided that the work of A-1 was more approprinte to the Waste Volume Reduction Facility Program since it is aimed at the design of instrumentation which will be used in the reduction facility to demonstrate the feasibility of the previously mentioned approach.

\section{TRANSURANIC WASTE SURVEY}

For the purposes of the Transuxanic Waste Research and Development Program, a solid transuranic waste is defined as any solid waste which contains, or potentially contains, transuranic elements in sufficient concentration or quantity that it must be disposed of under controlled conditions to minimize potential hazards to man or to the ecosystem. Solid transuranic wastes are placed into retrievable storage if they contain greater than 10 $n C i / g$ of transuranic contamination. Wastes contaminated to less than $10 \mathrm{nCi} / \mathrm{g}$ are disposed of nonretrievably.

In order to obtain background information necessary for characterization of the wastes to be expected, teams from the IASL program visited Hanford, Rocky Flats, Idako Falls, Mound Laboratory, anâ Savannah River, and obtained similar information from LASL. During the one or two day visits, a wide variety of topics were discussed, including a description of the types of materials in the waste, the volunes of the various types of wastes, the methods of handling and packaging, and the methods of storage. Because of the limited time available for this initial survey, many of the items were covered without great detail so that smissions dc occur in some areas. Also, the data were obtained from several people at each site with no deliberate attempt to cross-check the information, and the possibility of error resulting from misunderstanding or misinterpretation does exist. The authors wouzd be grateful to individuals or organizations reviewing this report if such mistakes were called to their attention. overall, the exercise was beneficial to the program in orienting the staff to the nature of the programs at other sites, in reviewing their specific problems and techniques, and in providing a general picture, with detail in some areas, of current waste management procedures. As the Transuranic Waste Research and Development study progresses, it is planned to periodically update the information presented below and to obtain increased detafl as such detail proves necessary to 
attaining the goals of the overall program. The sites visited represent a number of different types of operations and cover the major producers of solid transuranic waste and the disposal or storage sites at the AEC facilities. The Panford complex includes several contractors performing both production work and research and development work with plutonium. The major contractors visited were the Battelle Northwest Laboratory (BNWL), engaged in research and development work on many aspests of nuclear energy technology as well as studies in non-nuclear areas; the Atlantic Richfield Hanford Company (ARHCO), which operates the separations plants and the waste disposal and storage facilities; and the Hanforc Engineering Development Laboratory (HEDi), which carries out research and development work on advansed reactor fuels including those for the fast flux reactor. Mound Laboratory is primarily engaged in production and research work associated with ${ }^{238}$ pu heat sources for space and terrestrial applications. Savannah River is the major plutonium production plant since the Hanford reactors were shut down. In addition, Savannah River produces and purifies the ${ }^{238_{\mathrm{Pu}}}$ used for heat sources and maintains the AEC facilities for recovery of this material from highlevel scrap generated at other locations. Rocky Flats produces plutonium metal shapes and includes facilities for recovery of scrap. LASL is a research and development laboratory of broad atomic energy scope, including studies of the properties of the plutonium isotopes. Iimited processing facilities are associated with LASL work to permit development of processing improvements and the provision of special items required for other research. The Idaho Falls complex is the National Reactor Testing station with an associated plant for the recovery of uranium and plutonium from irradiated fuels. However, little transuranic waste is generated at this site, and the visit was primarily oriented towards the disposal and storage facilities.

\section{A. Description of Waste Streams}

Solid wastes consist of a wide variety of materials originating from different places in a given work area. In order to provide some description of the general types of waste matrices generated and the variability of their contents, an attempt was made to classify the waste streams into several categories so that these could be reviewed as individual entities.

1. Laboratory Trash (Room Trash). This waste consists of the miscellaneous materials which are used in the laboratories or rooms outside of the direct process enclosures. It varies in composition from day to day and from room to room, depending upon the type of work being carried out and, possibly, on the work habits of the operator. Because the contamination level is normally low, it is difficult or impossible by present technigues to assay the material for contamination; much of it is therefore discarded as nonretrievable waste (< $10 \mathrm{nCi} / \mathrm{g}$ ). It makes up the bulk of the combustible wastes so that the composition is of considerable interest in defining further steps needed in an overall volume reduction program.

An estimate of the composition of the waste matrix was obtained from each of the sites surveyed (Table I). These values are to be regarded only as approximations of the long-term overall average because of the variations noted above.

2. Line-Generated Trash. The linegenerated trash consists of miscellaneous materials which are used inside processing enclosures, guch as glove boxes. At most sites, the composition is siluilar to that of the room-generated trash, having a relatively high fraction of combustible material. However, the contamination level is usually considerably higher than that of the room-generated trash. Some portion of 
TABLE I

ESTIMATED COMPOSITION OF LABORATORY TRASH (WEIGHT PERCENT)

\begin{tabular}{|c|c|c|c|c|c|}
\hline Material & Hanford & LASL* & Mound & Rocky Flats & Savannah \\
\hline Paper \& rags & 18 & 46 & 50 & 30 & 53 \\
\hline Rubioer & 15 & 7 & 25 & 20 & 25 \\
\hline Plastics & 20 & 9 & 20 & 50 & 4 \\
\hline Glass & 1 & 17 & - & - & - \\
\hline Metal & 30 & 21 & - & - & - \\
\hline Misc. & 16 & - & 5 & - & 13 \\
\hline
\end{tabular}

*Data obtaired from a sorting experiment involving 2,500 pounds of trash from six laboratory locations considered to be representative of the overall laboratory irash, noi just the plutonium facilities.

the more highly contaminated material will be recycled for recovery of the transuranic elements with reduction usually by incineration and leaching of the ash. The residie from such processes is included in the linegenerated trash. A summary of the composition of this waste category at each location is given in Table II with the same caveat about the accuracy as was given for the room-generated trash.

3. Iiguid Effluent Treatment sludges. At Los Alamos, Rocky Flats, and Mound Laboratory the aqueous effluents are treated by a precipitation process to remove radio- active contaminants to such a level that the remaining water can be discharged to the environs. The contaminants carried in these effluents are transferred to the precipitate or sludge, which then forms the "solid" transuranic waste. At Savannah River and Hanford the liquid effluents are not treated but are disposed of by other means. Hanford is planning to treat animal excrements in the future by the production of aluminum hydroxide sludge following initial biological. treatment in a septic tank.

TABIE II

ESTIMATED COMPOSITION OF IINE-GENERATED TRASH (WEIGHT PERCENT)

\begin{tabular}{|c|c|c|c|c|c|}
\hline Material & Hanford & IASL & Mound & Rocky Flats & Savannah \\
\hline aper \& rags & (a) & (a) & + & 168 & 358 \\
\hline Rubber & + & + & + & 158 & 308 \\
\hline lastics & $+(b)$ & + & + & 368 & 358 \\
\hline Lisc. & - & - & - & $338(c)$ & - \\
\hline
\end{tabular}

+Indicates this material to be a major fraction but estimated percentages not available.

(a) Generally incinerated for plutonium recovery; leached residue becomes part of waste.

(b) Polyethylene bottles and lucite glove box windows.

(c) 68 wooden filter frames; 58 liquid (water and acids); 48 metals; and 18 asbestos filter material. 
At Los Alamos two treatment plants are in operation. The first is the central plant for the laboratory complex, while the second treats the wastes from the plutonium processing site. In both cases the treatment process employs a precipitation step using ferric sulphate carrier, lime, trisodium phosphate, and a coagulant aid. At the central liquid waste treatment plant, which serves most of the laboratory buildings, the sludge, which contains ferric hydroxide, calcium phosphate, and calcium carbonate, is vacuum filtered on diatomaceous earth. This sludge contains 35-40\% solids with activities of $908{ }^{238} \mathrm{Pu}$ and 108 ${ }^{239} \mathrm{Pu}$. The liquid effluents from this process may be passed through ion exchange columns to remove strontium and cesium if these are present. The columns are regenerated with $6 \mathrm{~N}$ nitric acid which is neutralized with sodium hydroxide. The strontium is precipitated with sodium carbonate, lime, ferric sulphate, and strontium nitrate; and the sludge is then included in the retrievable wastes. The sludge from the plutonium processing plant effluent treatment along with varying quantities of neutralized americium waste, potassium hydroxics scrubbing solution, neutralized strip waste, and small quantities of other solutions, is mixed with cement in a pug mill for disposal.

At Mound Laboratory the transuranic aqueous wastes are treated by precipitation, flocculation, and settling to produce a sludge which is mixed with cement.

At Rocky Flats the treatment is similar to that at Los Alamos with the resulting sludge being neutral to slightly basic. These sludges are mixed with cement to produce a waste containing diatomaceous earth, water, and metal hydroxides, nitrates, and chlorides.

4. Oils, Greases, and combustible Liquids. Oils and combustible liquids are used as lubricants for equipment or machining and as solvents. These materials, which may become contaminated during use, comprise a waste stream of some importance because of their generally mobile and frequently flammabie nature. Although they are usually liquids in their raw form, oils and solvents are included in this survey because they are frequently mixed with a sorbing solid and placed in the same channels for disposal or storage as the solid wastes. At several of the sites visited a portion of the oils and solvents was burned. Noncombustible silicone-type fluids are finding increased use as lubricants in plutonium processing operations. When contaminated, these are, for the most part, disposed of by means of absorption onto inert materials, followed by storage with other solid transuranic wastes.

At Hanford the major source of oils was vacuum pump oil, with some machining and cutting oils. ARHCO also has an accumulation of lard oil. At Los Alamos the vacuum pump oil again represented the largest volume but with contributions from Dow Corning Dielectric fluid 200 (dimethyl silicone) for heat treating, Mobil Vactra \#2 hydraulic fluid for the computerized lathe, and John Craine Lapping Vehicle 3-M containing suspended silicone carbide. Rags soaked with oils or solvents also originate in the dry boxes at this location. similar types of oils and solvents are found at Rocky Flats with lathe coolant being the rajor constituent. Several drums of paint thinner are being held onsite pending a decision as to theil disposal. At Savannah River the tributyl phosphate with a kerosene diluent used in the solvent extraction process is the primary source of combustible liquids. The small amount of other oils is mixed with the kerosene for burning.

\section{Equipment and Metals. At all} locations, discarded equipment constitutes a significant portion of the wastes. At most of the sites, small itemis. which will. fit into the solid waste packages are handled along with the room- or line-generated trash. A more troublesome problen is 
the large equipment such as glove boxes, obsolete lathes, and similar relatively massive devices. They are neither easily reduced in size nor easily monitored for contamination. In some cases, it would be possible to store this equipment for future use in contaminated work. However, the lack of adequate warehouse facilities for such potentially contaminated items and the regulations on the length of time that unused equipment can be stored essentially pr.clude its reuse; and the equipment is discarded as waste.

\section{Building Debris. Building debris} covers a wide variety of materials including building materials and built-in equipment such as blowers and filter housings. It results either from the renovation of a building or portion of a building or from the complete demolition of a structure which has lost its usefulness. Thus, it is characterized by its intermittent occurrence and by the diversity of materials found in the matrix. This type of waste may assume greater importance in the future as current facilities are decommissioned or are upgraded to meet new, more rigorous, safety standards.

B. General Waste Management Practices

1. Hanford. The transuranic isotopes handled at Hanford are chiefly ${ }^{238} \mathrm{Pu}$ and ${ }^{239} \mathrm{Pu}$. Sorting of the wastes into transuranic and nontransuranic contamination is accomplished by segregation of the facilities in which these isotopes are handled. sorting into the general classes of combustible and noncombustible is accomplished at the source of the waste.

Any material contaminated to greater than $0.1 \mathrm{nCi} / \mathrm{g}$ of matrix and less than the recovery limit is placed into retrievable storage. The current lower limit for recovery of the plutonium is $0.5 \mathrm{~g}^{239} \mathrm{Pu} / \mathrm{ft}^{3}$, but as much as 10-50 g per package (1-7 $\mathrm{g} / \mathrm{ft}^{3}$ ) may be discarded if several unsuccessful attempts to remove the plutonium have been made.

When the activity level is too low to be measured in the packaged wastes, the contamination level defining the method of handing is assigned from knowledge of the general contamination levels in the area in which the waste is generated. ARHCO passes all drums through a NaI passive neutron gamma counter to detect excessive contamination levels.

waste managment practices include the prohibition of packaging materials from entering the contaminated areas and the reuse of shipping containers wherever possible. All oxidizing materials, including nitrates, are prohibited from combustible wastes. For example, rags used to wipe up spills of such oxidants must be rinsed with water before being placed in a disposal container. ARHCO also prohibits glassware from the transuranic trash and reuses the giass containers wherever possible. Free liquids may not be included in solid waste packages.

Routine wastes are collected by the janitors twice per week and are placed in drums on a loading dock where the drums are sealed. Larger items or special items are collected after specific arrangements have been made.

2. Ios Alamos. The transuranic contaminants at Los Alamos are primarily weapons-grade plutonium $\left({ }^{239} \mathrm{Pu}\right.$ containing about $68^{240} \mathrm{Pu}$ ) and heat-source ${ }^{238} \mathrm{Pu}$. In addition, some waste streams contain significant quantities of ${ }^{241_{A n}}$ resulting from the separation of this daughter of ${ }^{241} \mathrm{Pu}$ during processing. Segregation of the wastes into transuranic and nontransuranic occurs through the separation of the areas in which these two types of materials are handled. Combustible and noncombustible materials are not segregated.

General room trash is usually considered to be nonretrievable because of the normal levels of activities encountered in these areas. Building debris is usually in the nonretrievable category although several items of building equipment may fall within the retrievable category. The 
usual line trash is disposed of nonretrievably if it contains less than $0.1 \mathrm{~g}$ of plutonium per package (generally a cardboard box containing $2 \mathrm{ft}^{3}$ of trash), is placed in retrievable storage if it contains between $0.1 \mathrm{~g}$ and $0.5 \mathrm{~g}$ per package, or is sent to recovery if it contains greater than $0.5 \mathrm{~g}$ pex package. Plutonium -238 wastes containing less than $0.05 \mathrm{~g}$ of ${ }^{238} \mathrm{Pu}$ per $30-$ gallon drum are placed in retrievable storage. Higher levels are classified as scrap and are shipped to Savannah River for eventual recovery.

Each container of waste from the plutonium processing facilities is routinely routed through a neutron counter to detect excess quantities of plutonium and for accountability purposes. This system detects the spontaneous fission neutrons from $240_{\mathrm{Pu}}$ and can detect about $100 \mathrm{mg}$ of the weaponsgrade plutonium per drum in a matrix of low density materials. scanning of the gamma ray spectrum with a Ge(Li) detector is used for assay of ${ }^{238} \mathrm{Pu}$ scrap and waste materials, wastes where there is some uncertainty of the isotopic composition of the contaminants, and wastes containing high levels of chemical impurities (for example, fluorides) which give rise to excessively high neutron counts. The contamination levels of the sludges from the liquid effluent waste treatment plants are determined by analysis of the influent and the effluent liquid streams along with the volume of sludge produced during the period, and therefore represent an arerage over some period of operation.

Packaging materials such as crates are generally removed from items of supply and equipment before the material is brought into the building and are disposed of as uncontaminated trash. In the new plutonium processing facilities now under dejign specific areas are allocated for this purpose. Procedures are established to exclude glassware and reagent bottles containing strong oxidizing agents from the wastes.

3. Mound Laboratory. The transuranic waste at Mound Laboratory arises from con- tamination with heat-source ${ }^{238} \mathrm{Pu}$ which contains 168 by weight ${ }^{239} \mathrm{Pu}$. Sorting of specific waste types is not done, nor is there a defined program to separate combustibles from noncombustibles.

Since the wastes from Mound are sent to commercial burial opexations, the primar? classification of activity levels is based upon the regulations of the Department of Transportation covering packaging during transport. These are as follows:

$\begin{array}{ll}\text { Low Specific Activity } & 0.1 \mu \mathrm{Ci} / \mathrm{g} \\ \text { Type B } & 1 \mu \mathrm{Ci} \mathrm{to} 20 \mathrm{ci} / \mathrm{pkg} \\ \text { Large Quantity } & >20 \mathrm{ci} / \mathrm{pkg}\end{array}$

To provide assay before disposal, all wastes generated in the glove-box lines are packaged in ice cream cartons and are sent on a conveyor inside the glove-box line to a central counting area. Here, the contamination levels are determined by gamina scanning, and containers having less than recoverable amounts are bagged out of the line for disposal.

Room trash is collected from the rooms daily but remains at the building for a few days before removal to a central holding area, a large room about $40^{\prime} \times 20^{\prime}$ where the material is held until a full load accumulates.

Recently, a waste management group has been formed at the Laboratory to initiate improvement of practices.

4. Rocky Flats. The transuranic materials at Rocky Flats are weapons-grade plutonium and depleted uranium. The contamination in the wastes averages ten weight percent or greater in $241_{\mathrm{Am}}$. A sophisticated sorting system carried out by the group generating the waste is in effect for the purpose of improving the assay procedures used on the packaged waste. Some 50 categories, most of which are specialized, are used, including:

First-stage sludge
Second-stage sludge
Grease
Special set-ups
Salt
Graphite molds

First-stage sludge

sludge

Special set-ups

Graphite molds 


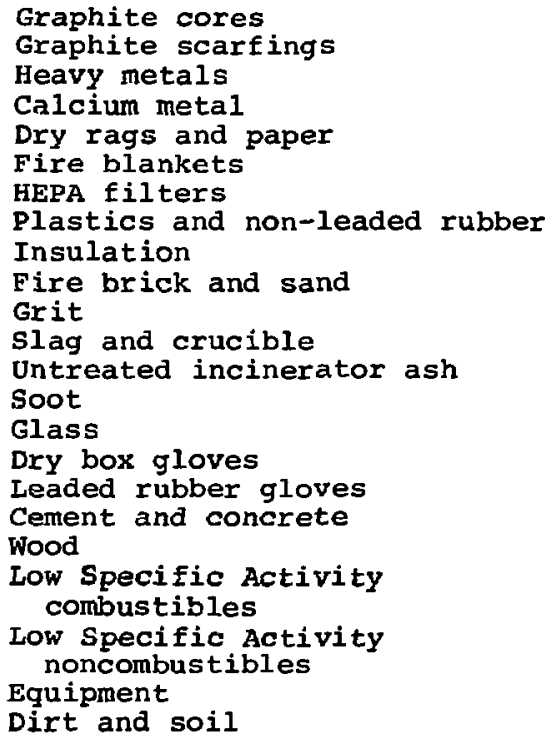

The wastes are designated retrievable or noncetrievable using the $10 \mathrm{nCi} / \mathrm{g}$ level of radioactivity. In addition, since the wastes are to be shipped to Idaho Falls, the contaminurion levels are classified according to the DOT regulations as described for Mound Laboratory. The lower limit for recycle of the waste through the recovery operation varies with the type of waste matrix, ranging between 0.1 and 3.5 grams of plutonium per kilogram of waste.

Packages are routinely monitored by gamma scanning with a sensitivity of about one gram of plutonium per drum. The device is calibrated for each specific waste type to permit accounting for self-adsorption and scatter. The sludges are analyzed in the laboratory for their plutonium content.

The current efforts on waste management at Rocky flats may be the most advanced of any of the sites visited. All wastes originating within the production areas are shipped to Idaho Falls for storage, with local burial in a sanitary landfill confined strictly to those materials originating outside of these areas. The drums received by the waste management operation are checked, and any that contain less than 70 pounds of material or which have evidence of free liquids (such as material leaking from the drum) are returned to the originator. Rags or wipes which have contacted strong acids are rinsed with a soda ash solution before disposal. Currently, they are investigating possible substitutes for chlorinated plastics (such as polyvinyl chloride) for uses such as gloves.

5. Savannah River. The transuranic contaminants in the wastes at Savannah River are both heat-source ${ }^{238} \mathrm{Pu}$ and weaponsgrade plutonium. Sorting into combustibles and noncombustibles is accomplished at the source of the wastes.

Currently the wastes are segregated into those having more than $0.1 \mathrm{Ci}$ per package and those having less. starting in FY 1974, those wastes with greater than 10 $\mathrm{nCi} / \mathrm{g}$ will be placed into retrievable storage.

Larger volumes of waste are collected from the generating area by the janitors and are placed in an onsite dumpster for pickup. Smaller amounts are placed in designated areas for pickup by a waste handling truck. In both cases, collections are made daily.

C. Treatment, Packaging, and Transport

1. Hanford. Greater than $95 \%$ of the transuranic wastes are packaged in $10 \mathrm{mil}$ polyethylene bags contained in 55-gallon drums. The room wastes are usually compacted slightly by hand while the drum is being filled. Additional treatment is not used for these wastes, although ARHCO has procured a proto type compactor which will reduce the volume of the room trash by an estimated factor of $4: 1$ in a 55-gallon drum. Oils, fats, and other liquids are combined with an absorbent such as vermiculite, sawdust, or Sorbal before packaging in a drum. An accumulation of lard oil from past years is currently being burned by feeding it onto the feed belt of an incinerator.

Most of the drums used for packaging are purchased as reconditioned drums. The insides are coated with sherwin-williams 
Kem Acid and Alkali Epoxy to a $5 \mathrm{mil}$ minimum thickness for dry wastes and with Sherwin-Williams Kem Cati-Coat to a $10 \mathrm{mil}$ minimum thickness for damp wastes. The drums are labeled as containing radioactive wastes and have both a code number on the drum and a label containing data as to the origin of the wastes with, in some cases, additional information on the specific contents.

When filled, the drums are placed outside on a loading dock to await transportation to the ARHCO storage facilities. The drums are transported from HEDL and BNWL on either a pickup truck or an enclosed twoton truck equipped with a hydraulic lift tailgate. The loading is accomplished manually. The transport is over roads which are restricted to the public. Any drum found to be leaking at the ARHCO facilities is returned to the originator. Since the drums are placed in storage in the ARHCO facilities twice per week, the time of temporary storage is brief.

Highly contaminated materials, such as filters from process air systems, or ovexsized equipment, such as a glove box, are placed in 20-ton reinforced concrete boxes.

The heavier containers may be lept at the generating site for several months before pickup and transport to the ARHCO facilities. These packages are loaded by winches or cranes and are generally transported by rail, again within an AEC-controlled area.

\section{Los Alamos.}

The nonretrievable room-generated trash is collected in cardboard boxes lined with $5 \mathrm{mil}$ polyethylene bags. In the laboratory the boxes are placed in 30-gallon drums fitted with fire-retardant lids. When the boxes are filled, they are removed from the arums, taped closed, and labeled in wax pencil or ink with the room number, the date, and the destination (the contaminated disposal area). In the plutonium handling facilities, these boxes along with the line-generated trash are assayed for plutonium content. If no activity is detected, the taped cardboard boxes are then placed in a Dempster Dumpster stationed outside the laboratory building. Small-sized building debris having an estimated activity below $10 \mathrm{nCi} / \mathrm{g}$ is also placed in cardboard boxes for nonretrievablo storage.

Nonrecoverable line wastes which have been sealed into one or two polyethylene bags and some building debris contaminated to levels above $10 \mathrm{nCi} / \mathrm{g}$ are placed into 55-galion drums for retrievable storage. Contaminated pipe, equipment, and some building debris above the retrievable limit are placed in plywood crates $4^{\prime} \times 4^{\prime} \times 8^{\prime}$. Unlined $17 \mathrm{C}$ steel drums have been used for the storage of the sluage from the central waste treatment area. These drums are single trip containers witi removable heads, and no quality control checks are made on the containers before use. Recently, these drums were found to be corroding through from the interior after less than one year of storage. Ninety mil polyethylene liners (as used at Rocky Flats) are now used in all sludge drums to prevent such corrosive attack by the sludge on the drum. Lids are heat welded to the liners.

3. Mound Laboratory. Drums used for the shipping of the wastes are DOT-specified 17C 30-galion and 55-gallon drums. These arums are spot checked for compliance with the specifications when received, and failure of any single drum in this check results in the return of the entire lot to the manufacturer. No specific drum liners are used for trash although the waste itself is sealed in small polyethylene bags. A number of household type compactors have been placed in the laboratories. However, the response to these devices by the operating people has been poor, and they are not used with any frequency. Drums used for the shipment of liquid waste treatment sludge are lined with polyethylene. oils, fats, and liquids are absorbed on materials such as vermiculite, Sorbal, or ground 
corn cobs before shipping in arums. The drum is labeled with an embossed plastic tape placed on the lid.

Boxes $4^{\prime} \times 4^{\prime} \times 7^{\prime}$ are used for large volumes of waste materials (such as building debris) and for oversized items. These boxes are made of $3 / 4^{\prime \prime}$ marine-grade plywood and are labeled with a wax pencil and a paper label listing the contents. In FY 1972, B68 of the Low Specific Activity wastes and 538 of the Type $B$ wastes were shipped in these boxes.

The Low Specific Activity wastes are transported to the burial area in trucks owned by the commercial service. The Type $B$ wastes are shipped in AEC ATMX 600 railroad cars.

4. Rocky Flats. Compaction of certain of the waste types is carried out at Rocky Flats. Discarded drums are flattened in a drum crusher, and HEPA filters are compacted. In addition, each generating group has a household type compactor, and a minimum of 70 pounds has been placed on the quantity of waste which must be placed in a drum. A drum compactor in a glove box, which will compact line-generated trash by a factor of three or four to one, will go into operation shortly. All equipment is dismantled prior to packaging, and large pieces of equipment are cut to fit into the standard size boxes. An incinerator capable of handing $250 \mathrm{lb} / \mathrm{hr}$ is planned for the new building along with a vertical type hammer mill to crush HEPA filters. In the near future plans will be implemented for sorting and compaction with an expected volume reduction of about $3: 1$ for most waste types leaving the plant.

The containers used for most wastes are 17C drums, especiully produced by the U. S. Steel Corporation, which meet all DOT specifications except the drop test on the top chime at $45^{\circ}$. The drums are painted white to minimize the internal temperature while standing in the sun. Ninety mil thick polyethylene liners are used in all drums sent to retrievable storage, and 8 mil liners are used for the sanitary and nitrate sludges which are to be placed in nonretrievable storage. Oils and greases are absorbed on a solid such as vermiculite, Microcel, or diatomaceous earth and are referred to as "sludges" . Lathe oil is presently mixed with carbon tetrachloride (5 volume percent), combined with a bakelite base, and placed in a drum. The drums are labeled with two paper labels, a metal tag, and an embossed plastic tape label under the sealing ring. In addition, the drum number is written on the plastic liner with a grease pencil.

Wooden boxes $4^{\prime} \times 4^{\prime} \times 7^{\prime}$ are used for large pieces of equipment or for large volumes of material. The boxes are coated with 1/8" fiberglass and can contain up to 5,000 pounds of waste. The box is lined with an $8 \mathrm{mil}$ plastic liner which covers the top of the contents before the lid is nailed on. After packaging, the closures are sealed with fiberglass.

The boxes are stored outside in a field while awaiting shipment. The drums of retrievable waste are stored in a new unheated metal building which serves as a warehouse or are stored in their cargo containers. Drums of nonretrievable wastes are either stored in the warehouse or loaded directly onto the trailer truaks. The Low Specific Activity wastes are transported to Idaho Falls either in the trailer trucks or in railroad gondola cars. The more highly contaminated wastes are shipped in ATHX railroad cars.

5. Savannah River. The larger pieces of equipment, such as glove boxes, are cut up where possible. Combustible liquids are usually burned in an open pan in the incinerator with overfed air, and the burning pans are buried when a heavy residue builds up in the bottom. A newly received compactor is expected to reduce the volume of 
about 708 of the wastes with greater than $0.1 \mathrm{Ci}$ per package by a factor of about $4: 1$.

All wastes with greater than $0.1 \mathrm{Ci}$ per package are placed in 55-gallon drums. These drums are reconditioned with no specifications indicated for the drum or the gaskets. The top of the waste is covered with cardboard and a plastic sheet which extends under the gasket seal. The roomor line-generated wastes, which are coilected in cardboard boxes, are placea into a drum if monitoring detects greater than $0.1 \mathrm{Ci}$ per package. The steel drums are marked with a reference number and source designation. The containers are also labeled as radioactive waste and as combustible or noncombustible.

Metals, equipment, and building debris are packaged in $4^{\prime} \times 4^{\prime} \times 15^{\prime}$ wooden boxes.

The waste containers are picked up daily and are transported in marked 2-1/2 ton trucks or in dumpster carriers to the disposal area. Transport is over roads controlled by the AEC and not available to the public.

\section{Storage Methods and Conditions}

1. Hanford. The Hanford location is in a semiarid region east of the Cascade Mountains, which serve to block much of the moisture from the Pacific ocean. The average annual precipitation is about seven inches with the heaviest recorded rate being 1.68 inches in a period of six hours. The record annual snowfall is 12 inches. The maximum recorded air temperature is $115^{\circ} \mathrm{F}$, while the minimum is $-27^{\circ} \mathrm{F}$. The average temperature during the summer is about $74^{\circ} \mathrm{F}$, with a winter average of about $32^{\circ} \mathrm{F}$. The disposal facilities are located in the middle of the AEC-controlled area with a distance to the water table underlying the area of several hundred feet. The soil percolation rate varies in this immediate area from 5 to $10 \mathrm{gallons} / \mathrm{ft}^{2} / \mathrm{day}$. The current method of drum storage consists of a $V$-shaped trench 140 ' long with $12^{\prime}$ sides. The trench is lined with concrete and is sloped so that any free water collecting in it will drain to one end for monitoring. The drums are unloaded from the transport vehicle and immediately placed in the trench. The first layer of drums is inclined at a $45^{\circ}$ angle with succeeding layers lying on top of the first to provide a nearly square crosssection when the trench is filled. The trench will hold about 1,900 drums and costs about $\$ 31,000$ (about $\$ 2.22 / \mathrm{ft}^{3}$ of waste stored). When the trench is filled, it is covered with sheet metal and a $4^{\circ}$ layer of soil and gravel.

Large concrete boxes are buried in metal or concrete-lined trenches. Building debris will be packaged in concainers and stored in a structure provided with fans for ventilation; the exhaust air will be filtered.

Experience with retrievability is

limited. In one case, an eight year old drum of depleted uranium from Rocky Flats was retrieved after burial. This drum had only a few pinholes in the outer container, and the labels were still legible.

2. Los Alamos. The waste disposal and storage area is located on a mesa within the boundaries of the AEC-controlled site. These mesas have evolved through the erosion of the local tuff, a consolidated volcanic ash. The average annual precipitation at the primary laboratory facilities is about 18 inches per year with some decrease at the lower elevations where the disposal area is located. The maximum recorded rainfall is 3.48 inches and the maximum recorded snowfall is 18 inches in a 24-hour period. The maximum and minimum recorded air temperatures are $95^{\circ} \mathrm{F}$ and $-19^{\circ} \mathrm{F}$. The characteristics of the tuff and the rate of evaporation in the region are such that iittle, if any, water from precipitation enters the tuff of the mega. At this location the usable water aquifer is some thousand feet below the surface.

The retrievable storage consists of trenches about $400^{\prime}$ long, 25' deep, and $25^{\prime}$ 
wide excavated in the tuff by a bulldozer. Separate trenches are used for the sludges and for the other transuranic wastes. The drums of sludge are held in temporary storage at the trench until about 100 drums have accumulated. This requires about one or two months. The drums are then banded four together on a wooden pallet and the pallets stacked five-drums high in the trench. Drums and crates of other retrievable wastes are unloaded directly from the truck bringing them to the area and stacked in the trench. At present, the plan is to leave the trench uncovered until it is filled. The trench will then be roofed using prestressed concrete beams and a concrete slab covered by several feet of earth.

The nonretrievable wastes are buried in trenches similar to those used for retrievable wastes except that no cover is provided and dirt is placed over the wastes as they accumulate. Records are kept of each shipment showing the origin of the waste and the location in the trench where the material is buried.

oils in drums and metal containers are placed in a shaft drilled into the tuff, and the shaft is plugged with a concrete cap. The cement paste from the sludge produced from the liquid effluent treatment plant for the plutonium processing facilities is pumped into $60^{\prime}$ deep asphalt-1ined shafts where it is allowed to solidify. This latter operation is carried out at the plutonium processing facilities on a mesa similar to but several miles distant from the disposal area.

Retrieval of some of the packages has indicated a gerious corrosion problem with the liquid effluent treatment sludges. One 18 year old drum which had been buried was badly corroded when retrieved. Recently, one year old arums of this sludge in the retrievable storage trench have developed leaks due to internal corrosion; the current drums are now equipped with the polyethylene liners used at Rocky Flats. Pressurization and venting of some ${ }^{238} \mathrm{Pu}$ scrap containers to be sent to Savannah River has been reported. These have been confined to those containers with quantities of near 40 grams in 3 -gallon containers.

3. Mound Laboratory. The wastes from Mound Laboratory are shipped to commercial burial grounds in West Valley, New York, and in Moorehead, Kentucky. These sites were not visited during the survey.

4. Rocky Flats. The transuranic wastes from Rocky Flats are stored at Idaho Falls.

5. Savannah River. The disposal area is on AEC-controlled land in a region where the water table is not far below the surface. Annual average precipitation is about 40 inches. The maximum temperature in the area is about $97^{\circ} \mathrm{F}$ and the minimum about $15^{\circ} \mathrm{F}$.

Wastes with greater than $0.1 \mathrm{Ci}$ per package in 55-galion drums are placed in $6^{\prime} \times 6^{\prime}$ concrete culverts, and the culverts are stored in a trench and covered with earth. Each culvert has a reference number stamped into a stainless steel bay which is attached to the carbon steel lid-lift eye with a stainless steel wire.

The plywood boxes containing building debris and higher level wastes are placed on wet concrete pads in $6^{\prime}$ deep ditches. A 6" coating of concrete is then poured around the box. These packages would be retrievable only with some difficulty.

6. Idaho Falls. The area presently being used for twenty year retrievable storage consists of lava flows with surface soils ranging from a few inches to $20^{\prime}$ deep. Below this is basalt, the water table lying at about $600^{\circ}$. Although the precipitation at. the site averages less than 10 inches per year, there is some possibility of localized fluoding in adjacent areas due to flash storms.

Drums and boxes are unloaded from the rail cars manually or by crane. They may remain at the unloading site, seven 
miles from the storage area for up to a week if a backlog of boxes and drums exists. The containers are then transported by truck to the storage site, where they are unloaded by a forklift. The drums are handled with a drum "grabber" attachment to the forklift which is capable of picking up two 55-gallon drums and stacking them on end up to five drums high (about 15'). The "grabber", which does essentially no damage to the drums, costs about $\$ 400$. Present plans call for extension of the rail lines directly to the storage site, eliminating temporary storage problems and costly onsite trucking $(\$ 55,000$ in 1972).

The area now being used for retrievable storage is not suitable for underground storage, the maximum soil thickness being only one to two feet. Retrievable waste is stored on a ground-level 3" thick asphalt pad measuring about $740^{\prime} \times 150^{\prime}$. The pad is designed to slope to the center and to one end to allow water drainage. A $1^{\prime \prime}$ diameter pipe drains each $80^{\prime}$ cell (or compartmentalized unit); any water coming from completed cells will be monitored for contamination. In each cell, boxes are stacked around the outer edge of the pad to create a wall, and the double wall of boxes between cells is separated with a $3^{\prime}$ soilfilled firebreak. The drums are stacked on end five drums high within the wall of boxes. Sheets of 3/4" fire-resistant marine-grade plywood separate each layer. Filled cells are covered with plywood, plastic sheets, and 18" of soil which is planted with erosion-retarding grass. The entire area has been landscaped and is surrounded with a 3-5' high dike for drainage and flood control. The cost of storage, including pad construction, landscaping, dike construction, unloading and stacking, and all materials used, is $\$ 0.96 / \mathrm{ft}^{3}$ of waste. An inventory of the contents of each cell is maintained, and a few drums have been retrieved with relative ease.

only one drum fire has been reported at Idaho Falls. This drum contained pyro- phoric materials from a research and development area at Rocky Flats and was badly corroded from outside storage of several years. In one other instance, a fire occurred in a truck trailer containing 55gallon drums in transit from Rocky Flats. The fire apparently started in paper and pasteboard packings around the drums and was not discovered until the truck was opened for unloading at Idaho. Although the inside of the trailer was charred, none of the waste-filled drums had ruptured or showed signs of pressurization or leakage; the only observed effect was the partial melting of some of the plastic liners. E. Waste Volumes and Contamination Levels 1. Hanford. The total volume of transuranic waste stored by ARHCO in FY 1972 was about $31,000 \mathrm{ft}^{3}$ (containing 3,300 $g$ of plutonium); $27,000 \mathrm{ft}^{3}$ originated onsite. The packing density is five to seven pounds per $\mathrm{ft}^{3}$. Room- and line-generated trash is composed of about 908 by volume combustibles and comprises about $90 \%$ of the total transuranic waste. BNWL expects to treat liquid wastes from the Life sciences Laboratory, the sludge produced being only 20-100 $\mathrm{ft}^{3}$ per year. ARHCO disposes of 50100 gallons of oil per year, at least half of which is vacuum pump oil from HEDL. In addition, ARHCO has an accumulation of about 2,000 gallons of lard oil. Small equipment from the glove boxes and HEPA Eilters account for $10 \%$ of the waste at HEDL and 58 of that at BNWL. While the laboratories do not keep track of the exact amount of plutonium per drum, BNWL estimated amounts at less than $5 \mathrm{~g}$ (with the exception of drums containing hot HEPA filters).

2. Ios Alamos. The volume of transuranic waste handled in 1972 was about $114,000 \mathrm{ft}^{3}$, with about $10,500 \mathrm{ft}^{3}$ being placed into retrievable storage. About $17 \times 10^{6}$ gallons of aqueous waste were treated to produce ahnut $\epsilon, 600 \mathrm{ft}^{3}$ of sludge and $18,500 \mathrm{ft}^{3}$ of cement paste. The sludge was disposed of retrievably, while the cement paste was pumped into $60^{\prime}$ deep shafts. 
(The paste would be retrievable only with extreme difficulty.) The volume of waste oils is generally less than 2,000 gallons per year, the plutonium content being about $10^{-3}$ to $10^{-4} \mathrm{~g} / 1$ iter. The uncompacted densities of packaged wastes (as determined from a sorting experiment) are about $4 \mathrm{lb} /$ $f t^{3}$ paper and rags, $11 \mathrm{lb} / \mathrm{ft}^{3}$ rubber, $5 \mathrm{lb} / \mathrm{ft}^{3}$ plastics, $32 \mathrm{lb} / \mathrm{ft}^{3}$ glass, and $18 \mathrm{lb} / \mathrm{ft}^{3}$ metal.

3. Mound Laboratory. During FY 1972 about $150,000 \mathrm{ft}^{3}$ were shipped as Type $B$ and Large Quantity wastes. The total waste volume was about three times the normal quantity aue to a program of cleanup of the buildings. Of the Low Specific Activity material $\left(107,000 \mathrm{ft}^{3}\right)$ about $97,000 \mathrm{ft}^{3}$ originated in the processing plants and the laboratories with the other $10,000 \mathrm{ft}^{3} \mathrm{com}-$ ing from the liquid waste treatment facilities. About 115,000 $\mathrm{ft}^{3}$ of building debris was included in the FY 1972 total, but this is expected to decrease to about one-third of this volume in FY 1973.

The average ${ }^{238} \mathrm{Pu}$ contamination levels in the wastes were $75 \mu \mathrm{Ci} / \mathrm{g}$ for laboratory wastes in 30-gallon drums, $30 \mu \mathrm{Ci} / \mathrm{g}$ for $\mathrm{lab}-$ oratory wastes in 55-gallon drums, and 0.75 $\mu \mathrm{Ci} / \mathrm{g}$ for the liquid effluent treatment sludge in 30-gallon drums.

4. Rocky Flats. Rocky Flats placed about $125,000 \mathrm{ft}^{3}$ of its $300,000 \mathrm{ft}^{3}$ of transuranic waste into retrievable storage at Idaho Falls in FY 1972. Approximately 11,000 drums of sluage were shipped in 1972, constituting about $43 \%$ of the Low specific Activity wastes (sanitary and nitrate sludges) and about 498 of the higher level wastes (sludges produced from the treatment of transuranic-contaminated aqueous wastes). The average weight of a drum of room-generated trash is about $165 \mathrm{lb}$. Rocky Flats shipped $120,000 \mathrm{ft}^{3}$ of fire debris in 1972 . Although very little debris is now being shipped, the amount is expected to increase when new construction begins and old buildings are dismantled.

\section{Savannah River. Savannah River}

handled $78,000 \mathrm{ft}^{3}$ of transuranic waste in FY 1972 with 23,000 $\mathrm{ft}^{3}$ of this placed in culverts for retrievable storage. Approximately 58 of the total waste volume was metal in some form. At present, building debris also comprises about $5 \%$ of the total, but this figure is expected to increase in future years.

The Low Specific Activity wastes are estimated to average $0.01 \mathrm{Ci}$ per package, whereas room-generated trash usually contains less than $0.1 \mathrm{Ci}$ per package and linegenerated trash greater than $0.1 \mathrm{Ci}$ per package.

\section{F. Discussion}

The survey, while incomplete in many details, has indicated that all of the locations visited are working to achieve a satisfactory system for providing a twenty year retrievable storage capability for waste packages. Approaches to the problem" vary from site to site, although the Rocky Flats packaging and Idaho Falls storage are probably the most advanced and most capable of meeting the twenty year requirement, albeit at significant cost. However, because many factors remain to be investigated, there is no guarantee that any of the systems has a reasonably assured capability of reaching the twenty year goal.

One of the questions which arose during the survey relates to the types of records required and the amount of detail to be included in these records. Such records can be o; use in assessing the overall effectiveness of a waste management system and will be invaluable if a decision is made to treat the wastes, for example by incineration or calcination, after they are removed from storage. The minimum requirements for these two purposes will be considered as the LASL program progresses.

An observation of some interest to the overall waste management function was made at those locations where highly contaminated combustible materials are incinerated as a first step toward recovery of the contained plutonium. With the present technology 
there may be no overall volume reduction from incineration due to the waste produced from the necessary ancillary operations such as the HEPA filters from the air cleaning, sludges from the processing of scrubbing solutions, and the materials from incinerator maintenance. It is suggested that in future designing due consideration be given to volume reduction systems. If significant reduction in wasie generation cannot be attained, justification for the use of a process must be based on risk considerations involving the form of the waste placed into storage.

During the survey, some attenpt was made to obtain data on costs at each site. Costs varied widely depending upon the accounting system used, the types of charges made for the waste handling, and the degree of effort placed upon keeping waste cost records as a separate account. For this reason, cost numbers are not included in the survey but will be used in future considerations leading to the optimization of the waste management systems.

\section{PACKAGE CORROSION}

The container in which the radioactive materials are stored should be resistant to chemical corrosion and be mechanically strong to resist physical abuse in handling and transport. Initial corrosion tests were made on coupons from the 17C 55-gallon drums which are currently being used for storage of waste at IASL. Table III shows the results of the chemical analyses of selected portions of these drums.

As indicated, the drum material is nearly 1008 iron with a small amount of manganese, probably added to improve workability. The composition was not selected tc provide resistance to corrosion, and metals of this nature require protection if they are to survive for any length of time in a hostile environment.

Corrosive attack upon the metal container depends not only upon the chemical composition of the metal but also upon the chemical composition of the environment including its moisture content. Three soil samples obtained from the LASL storage pits were leached in the manner described below and the solutions analyzed to determine the dissolved ions which could be of importance in corrosion. The soils were screened through 4 mesh steel screen and dried at $110^{\circ} \mathrm{C}$. Weighed samples were then agitated with leach solutions for 84 hours, after

TABLE III

CHEMICAL ANALYSIS ${ }^{(a)}$ OF REPRESENTATIVE WASTE CONTAINER

\begin{tabular}{|c|c|c|c|c|c|c|}
\hline & Bottom & Side & Top & Rib & Sealing Ring & Bolt \\
\hline Fe & $99.6(8)$ & $99.6(8)$ & $99.6(z)$ & $99.6(8)$ & $99.5(8)$ & $99.4(8)$ \\
\hline C & 210 & 130 & 180 & 170 & 150 & $0.4(8)$ \\
\hline $\mathrm{Mn}$ & $0.4(8)$ & $0.4(8)$ & $0.4(8)$ & $0.5(8)$ & $0.4(8)$ & $0.5(8)$ \\
\hline $\mathrm{Ni}$ & 300 & 300 & 300 & 700 & 200 & 300 \\
\hline $\mathrm{Cr}$ & 200 & 200 & 200 & 200 & 200 & 400 \\
\hline $\mathrm{Cu}$ & 300 & 300 & 300 & 300 & 400 & 400 \\
\hline Al & 30 & 30 & 30 & 400 & 40 & 15 \\
\hline si & (b) & (b) & (b) & 600 & (b) & (b) \\
\hline
\end{tabular}

(a) Concentrations are ppm unless specified otherwise

(b) Negligible 
which time the leach solutions were filtered and analyzed. Three different liquids were used to leach the soils: (1) distilled $\mathrm{H}_{2} \mathrm{O}$ at $25^{\circ} \mathrm{C},(2)$ distilled $\mathrm{H}_{2} \mathrm{O}$ at $25^{\circ} \mathrm{C}$, continuously saturated with $\mathrm{CO}_{2}$ gas, and (3) distilled $\mathrm{H}_{2} \mathrm{O}$ refluxed at the boiling point of water (about $93^{\circ} \mathrm{C}$ at the altitude of Ios Alamos). The weight ratio of soil to leach solution was constant at 1:4. Table IV summarizes the results of these tests. It should be noted that increasing the temperature of the leach solution and the $\mathrm{CO}_{2}$ con- tent increases the total dissolved matter. The relative effect of the particular ions dissolved on the rate of corrosion has still to be determined.

The initial studies of corrosion of the 17C arum involved the sectioning of several drums and the introduction of test coupons into different soil environments in order to determine important mechanisms of corrosion. The seven drum section types tested were (1) top, (2) bottom, (3) side, (4) rib, (5) bung, (6) ring + rim + gasket

TABIE IV

ANALYSES OF LEACH SOLUTIONS FROM TEST SOIIS

\begin{tabular}{|c|c|c|c|c|c|c|c|c|c|}
\hline Location & \multicolumn{3}{|c|}{ Top } & \multicolumn{3}{|c|}{ Middle } & \multicolumn{3}{|c|}{ Bottom } \\
\hline $\begin{array}{l}\text { Soil capacity } \\
\text { for holding }\end{array}$ & \multicolumn{3}{|c|}{$0.176 \mathrm{~g} \mathrm{H}_{2} \mathrm{O} / \mathrm{g}$ soil } & \multicolumn{3}{|c|}{$0.335 \mathrm{~g} \mathrm{H}_{2} \mathrm{O} / \mathrm{g}$ soil } & \multicolumn{3}{|c|}{$0.300 \mathrm{~g} \mathrm{H}_{2} \mathrm{O} / \mathrm{g}$ soil } \\
\hline Leach Liquid & $\begin{array}{l}\mathrm{H}_{2} \mathrm{O} \\
25^{\circ} \mathrm{C}\end{array}$ & $\begin{array}{l}\mathrm{H}_{2} \mathrm{O}-\mathrm{CO}_{2} \\
25^{\circ} \mathrm{C}\end{array}$ & $\begin{array}{l}\mathrm{H}_{2} \mathrm{O}, \\
93^{\circ} \mathrm{C}\end{array}$ & $\begin{array}{l}\mathrm{H}_{2} \mathrm{O} \\
25^{\circ} \mathrm{C}\end{array}$ & $\begin{array}{l}\mathrm{H}_{2} \mathrm{O}-\mathrm{CO}_{2} \\
25^{\circ} \mathrm{C}\end{array}$ & $\begin{array}{l}\mathrm{H}_{2} \mathrm{O} \text {, } \\
93^{\circ} \mathrm{C}\end{array}$ & $\begin{array}{l}\mathrm{H}_{2} \mathrm{O} \\
25^{\circ} \mathrm{C}\end{array}$ & $\begin{array}{l}\mathrm{H}_{2} \mathrm{O}-\mathrm{CO}_{2} \\
25^{\circ} \mathrm{C}\end{array}$ & $\begin{array}{l}\mathrm{H}_{2} \mathrm{O}, \\
93^{\circ} \mathrm{C}\end{array}$ \\
\hline $\begin{array}{l}\text { ph of soln. } \\
\text { after soil } \\
\text { leach }\end{array}$ & 7.2 & 7.0 & 8.8 & 8.4 & 6.6 & 9.5 & 6.9 & 6.5 & 9.0 \\
\hline $\begin{array}{l}\text { Total mate- } \\
\text { rial dis- } \\
\text { solved in } \\
\text { leach soln., } \\
\mu \mathrm{g} / \mathrm{ml}\end{array}$ & 84 & 141 & 116 & 101 & 398 & 231 & 88 & 98 & 12.2 \\
\hline $\begin{array}{l}\text { Concentra- } \\
\text { tions, } \mu \mathrm{g} / \mathrm{ml}\end{array}$ & & & & & & & & & \\
\hline Na & 2.3 & 2.5 & 3.3 & 15.5 & 16.0 & 27.3 & 1.6 & $? .5$ & 2.3 \\
\hline $\mathbf{K}$ & 41.0 & 36.5 & 2.9 & 4.8 & 7.1 & 6.7 & 37.0 & 4.3 & 3.7 \\
\hline $\mathrm{Mg}$ & 1.1 & 3.7 & 0.07 & 0.24 & 6.3 & 0.015 & 0.93 & 1.8 & 0.08 \\
\hline $\mathrm{Ca}$ & 9.7 & 30 & 4.2 & 5.3 & 132 & 6.6 & 10.6 & 21 & 6.3 \\
\hline Al & $<1$ & $<1$ & $<1$ & $<1$ & $<1$ & $<1$ & $<1$ & $<1$ & $<1$ \\
\hline si & 6.7 & 8.2 & 29 & 11.8 & 11.7 & 72 & 6.9 & 3.7 & 27 \\
\hline $\mathrm{Fe}$ & $<0.1$ & $<0.1$ & 0.1 & $<0.1$ & $<0.1$ & $<0.02$ & $<0.1$ & $<0.1$ & $<0.04$ \\
\hline $\mathrm{Cl}$ & 0.6 & $<0.3$ & 0.3 & 0.8 & 0.5 & 0.8 & $<0.3$ & $<0.3$ & 0.3 \\
\hline $\mathbf{P}$ & 0.3 & $<0.3$ & $<0.3$ & $<0.3$ & 0.3 & $<0.3$ & 0.3 & $<0.3$ & $<0.3$ \\
\hline $\mathbf{s}$ & $<0.3$ & 0.3 & $<0.3$ & 0.6 & 0.7 & 0.7 & 0.4 & $<0.3$ & $<0.3$ \\
\hline $\mathbf{B r}$ & $<0.3$ & $<0.3$ & $<0.3$ & $<0.3$ & $<0.3$ & 0.7 & $<0.3$ & $<0.3$ & $<0.3$ \\
\hline I & $<0.1$ & $<0.1$ & $<0.3$ & $<0.1$ & $<0.1$ & $<0.1$ & $<0.1$ & $<0.1$ & $<0.1$ \\
\hline $\mathbf{F}$ & 0.33 & 0.19 & 0.31 & 1.27 & 0.61 & 1.78 & 0.19 & 0.19 & 0.27 \\
\hline
\end{tabular}


seal, and (7) bolt + ring. These portions were chosen in order to test the resistance of several parts of the drum to various types of corrosion, including stress, galvanic, and crevice corrosion, general attack, pitting, selective leaching, and intergranular attack. Square coupons, $5 \mathrm{~cm} \times 5 \mathrm{~cm}$, were cut from the drums and rinsed with acetone to remove any grease or oil. Most of the coupons were not polished prior to placement in the soil; however, the ring, rim, and seal combinations were cleaned and smoothed with emery paper, since they were corroded when they were received. Each specimen was placed in a prepared soil mixture in a glass container that was covered in order to maintain a constant moisture content. The soil matrices were chosen from LASI storage pits and included samples from the top, middle, and bottom of the pits. Water was added to each soil to give mixtures of 1008,508 , and 108 of soil rield capacity (determined from the weight of water held by a known weight of oven-dried soil after that soil has been soaked in water and allowed to drain on a coarse screen). These field capacities are listed in Table IV. Thus, each drum section type was exposed to nine different environments (three different soils and three different moisture contents).

After the coupons had been in the moist environment for one month, samples about $0.7 \mathrm{~cm} \times 0.7 \mathrm{~cm}$ were cut from the coupons and photomicrographed. Figures 1 through 3 show some of the typical types of corrosion observed. These figures show that certain portions of the drum are more susceptible to attack than others. Most severely attacked is the ring and rim seal (Fig. 1). Deep pitting is observed, as well as scaling and general attack. Corrosion is probably initiated by a combination of crevice and stress corrosion. portions of the drum side (Fig. $2 a$ and $2 b$ ) and the rib (Fig. 2c and 2d) also exhibit deep pitting and extensive general attack. These sec- tions of the drum are subject to stress corrosion. In particular, note the crack which developed in the specimen shown in Fig. 2d. The heavy scaling cbserved around the bungs (Fig. 3d) is evicience of galvanic and/or stress corrosion. The top and bot-tom sections of the drum exhibited very little corrosion in comparison with the other sections. The bolt which secures the retaining ring was not visibly attacked. Examination of the full set of photomicrographs of these samples indicates that unrelieved stress is of importance in the corrosion of the container.

In addition to the photomicrography, the micro hardness of several samples was measured using the Vickers scate. The hardness of samples which were worked very little, for example the top, bottom, side, and bolt, did not change significantly. The ring, rim, and seal combination and the drum rib, however, demonstrated a significant drop in hardness of 30 to 50 points on the vickers scale. The sections most susceptible to corrosion, as determined by microscopic examination, were the sections which also demonstrated changes in metallurgical properties. The only exception was the drum side, which was heavily corroded but which did not evidence a change in hardness.

In order to determine the rate of gen-. eral attack, several samples were examined using the electron microprobe. of immediate interest were the measured depths of the corrosion layers, which varied from 5 to $20 \mu \mathrm{m}$ depending upon the section type and its immediate environment. Examinations using the microprobe failed to note either intergranular attack or selective leaching.

\section{COMBUSTION STUDIES}

Unintentional ignition of stored combustible wastes can present a potential threat to the integrity of the packaging of the stored wastes. Determination of the 


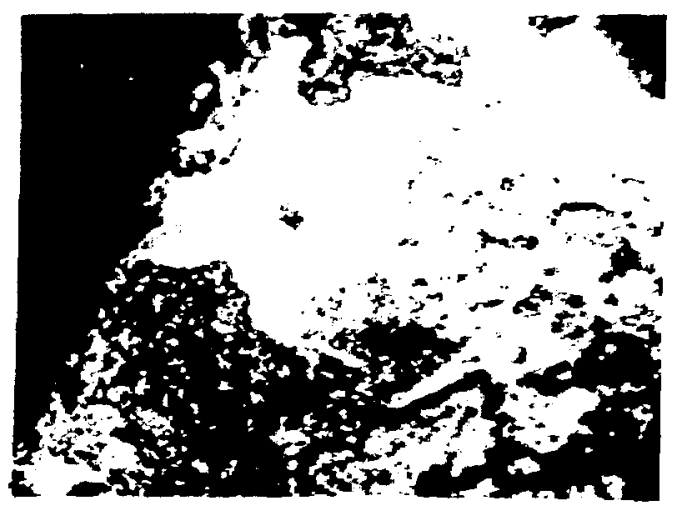

(a) Photomicrograph of Ring + Rim Seal (15x) after one month in contact with LASI bottom-soil, moisture content 1008 soil capacity.

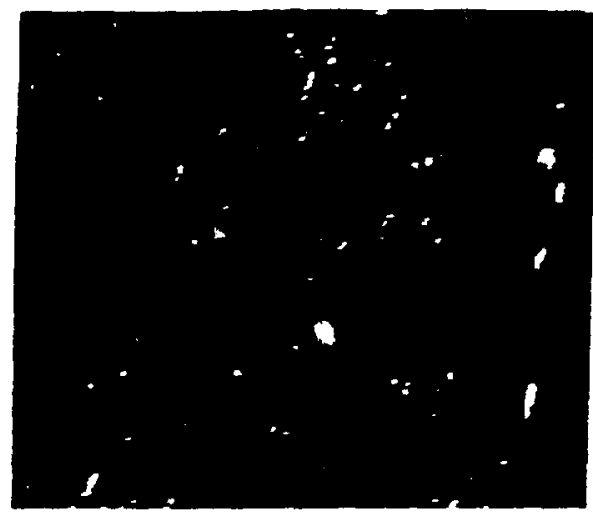

(c) Photomicrograph of Ring + Rim Seal (35x) after one month in contact with LASI bottom-soil, moisture content 508 soil capacity.

Fig. 1 Examples of corrosion of drum coupons.

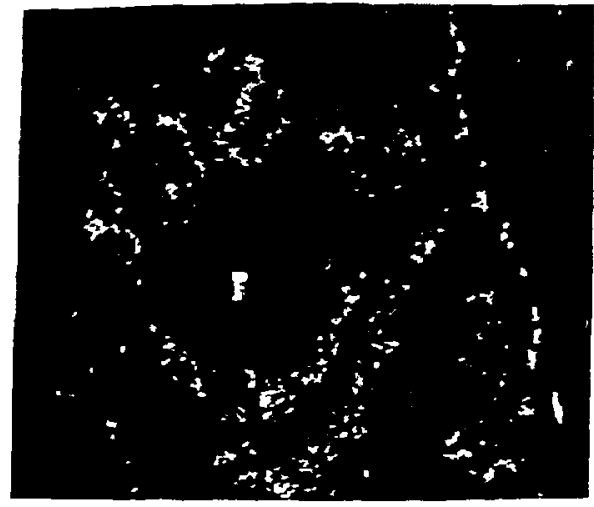

(b) Photomicrograph of Ring + Rim Seal (15x) after one month in contact with LASL top-soil, moisture content 508 soil capacity.

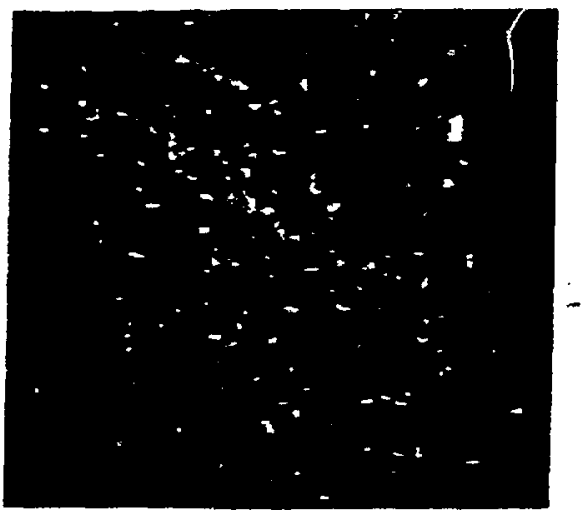

(d) Photomicrograph of Ring + Rim Seal (15x) after one month in contact with LASI mid-soil, moisture content 108 soil capacity. 


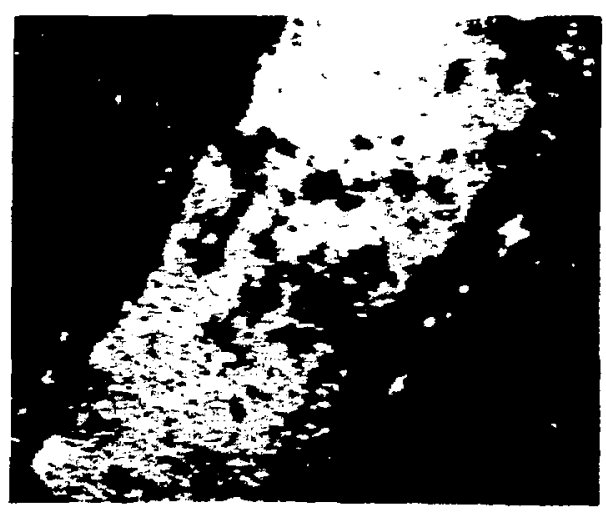

(a) Photomicrograph of drum side (15x) after one month in contact with LASI midsoil, moisture content 508 soil capacity.

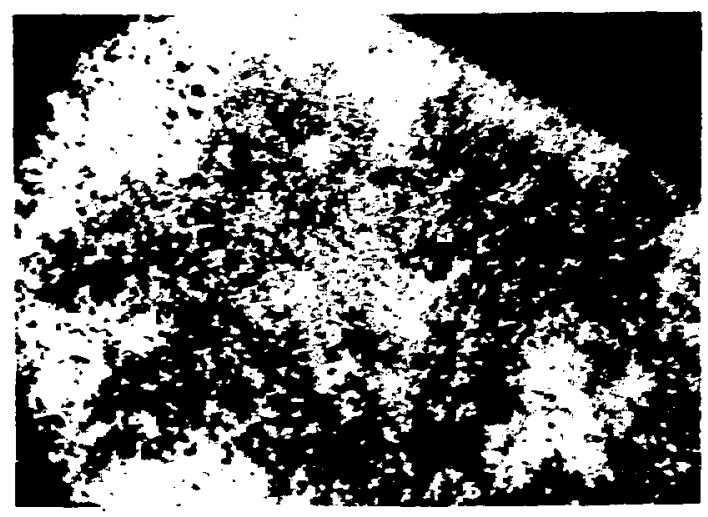

(b) Photomicrograph of drum side after one month in contact with LASI bottomsoil, moisture content 108 soil capacity.

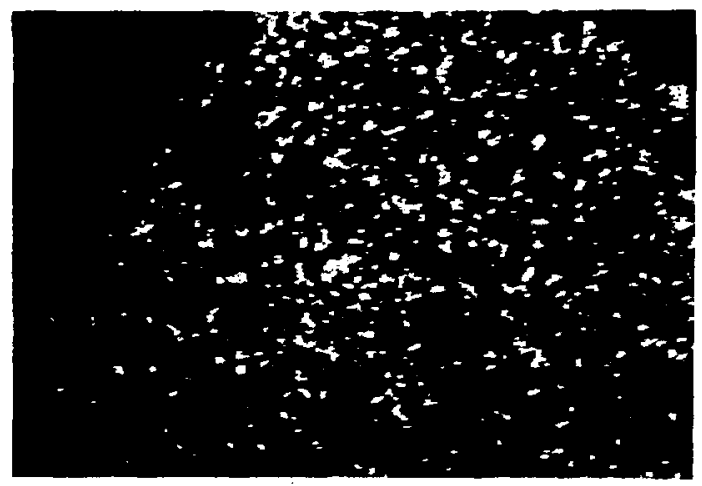

(d) Photomicrograph of drum rib (15x) after one month in contact with LASI Dottom-soil, moisture content 108 soil capacity.

Fig. 2. Examples of corrosion of drum coupons. 


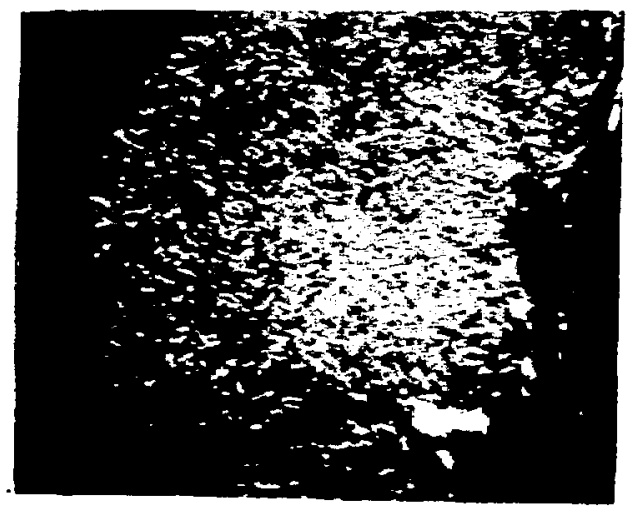

(a) Photomicrograph of arum bottom (15x) as received.

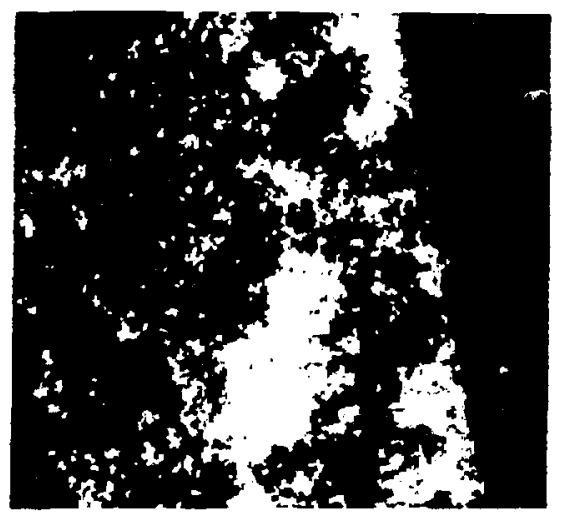

(c) Photomicrograph of arum top (15x) after one month in contact with LASL top soil, moisture content $50 \%$ soil capacity.

Fig. 3. Examples of corrosion of drum coupons.

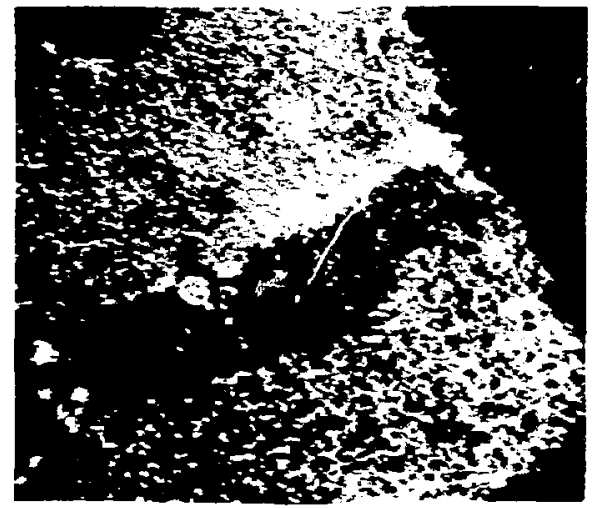

(b) Photomicrograph of drum bottom (15x) after one month in contact with LASL mid-soil, moisture content 1008 soil capacity.

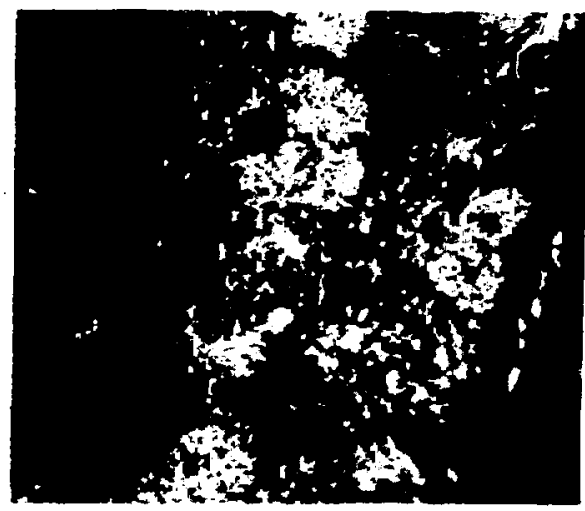

(d) Photomicrograph of arum bung (15x) after one month in contact with LASL bottom-soil, moisture content 1008 soil capacity. 
ignition temperatures in air of rags, paper, polyethylene, polyvinyl chloride, latex rubber, and butasol-neosol rubber has been completed. Between 2.5 and $5 \mathrm{~g}$ of the tesi material were loosely packed in a tube having one open end and an attached Nichromewire resistance heating element. The tube was then heated for about one hour. Warmup time for the system, which was initially at room temperature, was about five minutes.

The experimental results at the various test temperatures are shown in Table $v$. Decomposition did not occur at temperatures below $150^{\circ} \mathrm{C}$ although both polyethylene and polyvinyl chloride began to soften. At $200^{\circ} \mathrm{C}$ all test specimens began to char and decompose. Under the test conditions selected, none of the test specimens actually burned with a flame, even when thrust into a furnace preheated to $400^{\circ} \mathrm{C}$, although decomposition proceeded with the release of large quantities of gaseous products and dense smoke. Other materials may provide different problems, however. For example, an explosion resulting from the accidental heating to $250^{\circ} \mathrm{C}$ of hypalon-coated, leadloaded Neoprene rubber gloves has been reported. The flamable fumes released by decomposition of the glover were apparently ignited either by the exposed hot element in the drying oven or by sparking of the glove residues. 2

\section{v. LEACHING STUDIES}

In order to provide an initial aseessment of the movemant of plutoniur from wastes exposed to ground water, leaching teste were made uring even waste material: found In cowbuetible transuranic-contaminated wavter at IASI. Thene were (1) cloth work gloves, (2) Glefold hand towele, (3) cheesecloth, (4) scott assembly wipes, (5) Latex rubber gloves, (6) Scott Duraweve Hiping Towels, and (7) cellfibe Wiping Towels. Each waste matrix was "epiked" with known quantities $(80 \mathrm{mg})$ of plutonium as either a Pu $\left(\mathrm{NO}_{3}\right)_{4}$ solution (an approximately $1 \mathrm{H} \mathrm{HNO}_{3}$ solution obtained from the
LASL processing areas) or low-fired hypostoichiometric $\mathrm{PuO}_{2}$ (probably the oxide form found in most trash). Leach mixtures were prepared by the addition of $100 \mathrm{ml}$ of distilled water to $3 \mathrm{~g}$ of each of the "spiked" trash types. The leach solutions were periodically stirred and small samples extracted at intervals, filtered through $5 \mathrm{um}$ micropore filters, and the filtered solution analyzed for plutonium. In addition, identical plutonium-spiked trash samples were allowed to stand in air for selected times $(7$ and 28 days) before the leach water was added.

The percent of plutonium remaining in solution after filtration is listed in Table VI. Figures 4 and 5 illustrate the

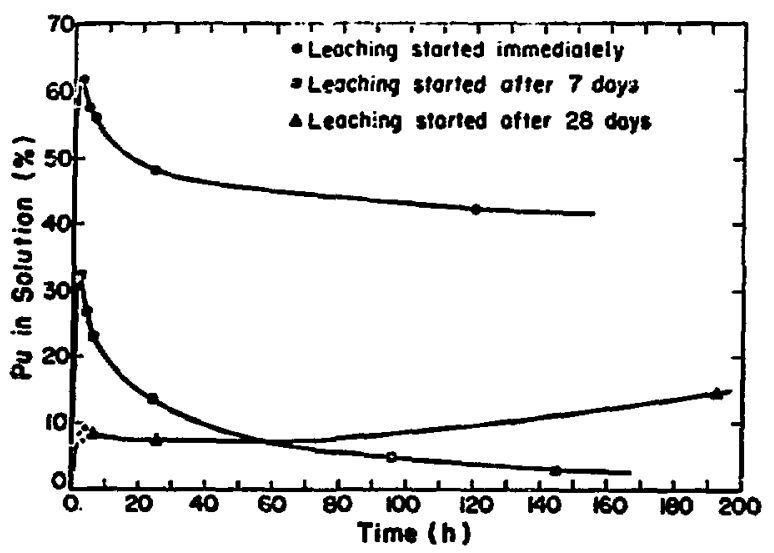

F19. 4. Plutonium in Solution after Ieaching from cellfibe Towel contalnIng Pu(NO$)_{4}$ Solution.

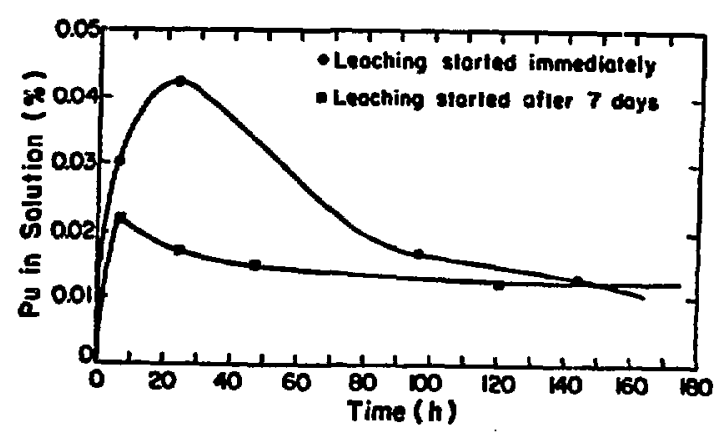

Fig. 5. Rlutonium in Solution after Leaching from cellfibe Towels containing $\mathrm{PuO}_{2}$. 
TABLE V

EXAMINATION OF WASTE MATERIALS AT ELEVATED TEMPERATURES

\begin{tabular}{|c|c|c|c|c|c|c|c|c|}
\hline Material & $\begin{array}{c}\text { (a) } \\
200^{\circ} \mathrm{C}\end{array}$ & $250^{\circ} \mathrm{C}$ & $300^{\circ} \mathrm{C}$ & $350^{\circ} \mathrm{C}$ & $400^{\circ} \mathrm{C}$ & $450^{\circ} \mathrm{C}$ & $\begin{array}{l}\text { Description } \\
\text { of Residue }\end{array}$ & $\begin{array}{l}\text { Material Heated } \\
\text { Directly to } 400^{\circ} \mathrm{C}\end{array}$ \\
\hline $\begin{array}{l}\text { Butasol- } \\
\text { Neosol } \\
\text { Glove }\end{array}$ & $\begin{array}{l}\text { Material } \\
\text { expands }\end{array}$ & No change & $\begin{array}{l}\text { Begins to } \\
\text { blister }\end{array}$ & $\begin{array}{l}\text { Begins to } \\
\text { char; odor- } \\
\text { ous gases \& a } \\
\text { little smoke } \\
\text { released }\end{array}$ & $\begin{array}{l}\text { Dense smoke } \\
\text { \& odor; contd. } \\
\text { shriveling of } \\
\text { materials as } \\
\text { oxidation } \\
\text { proceeds }\end{array}$ & $\begin{array}{l}\text { No change; } \\
\text { oxidation } \\
\text { complete }\end{array}$ & $\begin{array}{l}\text { White part } \\
\text { burned com- } \\
\text { pletely to } \\
\text { ash; black } \\
\text { part lost } \\
\text { all elastic- } \\
\text { ity and } \\
\text { turned brown }\end{array}$ & $\begin{array}{l}\text { Material smoldered } \\
\text { and oxidized; no } \\
\text { flame }\end{array}$ \\
\hline $\begin{array}{l}\text { Latex } \\
\text { Glove }\end{array}$ & $\begin{array}{l}\text { Glove melts } \\
\text { o starts to } \\
\text { char, odors } \\
\text { detected }\end{array}$ & $\begin{array}{l}\text { Oxidation } \\
\text { continues } \\
\text { with more } \\
\text { charring; } \\
\text { begins to } \\
\text { smoke }\end{array}$ & $\begin{array}{l}\text { Begins to } \\
\text { ash, smoking } \\
\text { continues }\end{array}$ & $\begin{array}{l}\text { Heavy, dense } \\
\text { smoke; ash- } \\
\text { ing contin- } \\
\text { ued }\end{array}$ & No change & $\begin{array}{l}\text { No change; } \\
\text { oxidation } \\
\text { complete }\end{array}$ & Black ash & $\begin{array}{l}\text { No flame; oxida- } \\
\text { tion more rapid; } \\
\text { same physical } \\
\text { changes }\end{array}$ \\
\hline $\begin{array}{l}\text { Cheese- } \\
\text { cloth }\end{array}$ & $\begin{array}{l}\text { Decomposi- } \\
\text { tion begins } \\
\text { with char- } \\
\text { ring, smok- } \\
\text { ing odor- } \\
\text { ous producte }\end{array}$ & $\begin{array}{l}\text { Oxidation } \\
\text { proceeds }\end{array}$ & $\begin{array}{l}\text { Dense smoke: } \\
\text { no flame; } \\
\text { rapid decom- } \\
\text { position; } \\
\text { after } 10 \text { min } \\
\text { smoking } \\
\text { ceases } \\
\end{array}$ & No change & No change & No change & $\begin{array}{l}\text { Black ash; } \\
\text { heavy carbon } \\
\text { residue }\end{array}$ & $\begin{array}{l}\text { Decomposition } \\
\text { as before; no } \\
\text { flame }\end{array}$ \\
\hline $\begin{array}{l}\text { Cellulose } \\
\text { (Paper, } \\
\text { Ximulpes) }\end{array}$ & $\begin{array}{l}\text { A little } \\
\text { charring } \\
\text { around } \\
\text { the edges; } \\
\text { no smoke }\end{array}$ & $\begin{array}{l}\text { Piece chars } \\
\text { rapidly; } \\
\text { heavy re- } \\
\text { lease of a } \\
\text { light col- } \\
\text { ored smoke } \\
\text { c odorous } \\
\text { gases }\end{array}$ & $\begin{array}{l}\text { Heavier } \\
\text { smoking; } \\
\text { charring. } \\
\text { After } 10 \mathrm{~min} \\
\text { smoking } \\
\text { ceases \& ox- } \\
\text { idation com- } \\
\text { plete }\end{array}$ & No change & No change & No change & White ash & $\begin{array}{l}\text { Rapid oxidation } \\
\text { \& decomposition; } \\
\text { heavy smoking \& } \\
\text { gases; no flame }\end{array}$ \\
\hline $\begin{array}{l}\text { Polyvinyl } \\
\text { chloride }\end{array}$ & $\begin{array}{l}\text { Charring, no } \\
\text { smoke: aroma } \\
\text { of decomposi- } \\
\text { tion pro- } \\
\text { ducts }\end{array}$ & $\begin{array}{l}\text { Same as } \\
\text { at } 200^{\circ} \mathrm{C}\end{array}$ & $\begin{array}{l}\text { Same as } \\
\text { at } 200^{\circ} \mathrm{C}\end{array}$ & $\begin{array}{l}\text { Same as } \\
\text { at } 200^{\circ} \mathrm{C}\end{array}$ & $\begin{array}{l}\text { Smoking; } \\
\text { pungent } \\
\text { aroma }\end{array}$ & No change & $\begin{array}{l}\text { Dark amor- } \\
\text { phous melt } \\
\text { which solidi- } \\
\text { fied upon } \\
\text { cooling }\end{array}$ & $\begin{array}{l}\text { More rapld } \\
\text { decomposition; } \\
\text { no flame }\end{array}$ \\
\hline $\begin{array}{l}\text { Poly- } \\
\text { ethylene }\end{array}$ & $\begin{array}{l}\text { Decomposi- } \\
\text { tion with } \\
\text { darkening } \\
\text { of material; } \\
\text { light color- } \\
\text { ed smoke \& } \\
\text { pungent aroma }\end{array}$ & $\begin{array}{l}\text { Very heavy } \\
\text { snoking as } \\
\text { decomposi- } \\
\text { tion } \\
\text { progresses }\end{array}$ & $\begin{array}{l}\text { Same as } \\
\text { at } 250^{\circ} \mathrm{C}\end{array}$ & $\begin{array}{l}\text { Same as } \\
\text { at } 250^{\circ} \mathrm{C}\end{array}$ & $\begin{array}{l}\text { Same as } \\
\text { at } 250^{\circ} \mathrm{C}\end{array}$ & No change & $\begin{array}{l}\text { Dark brown } \\
\text { amorphous } \\
\text { "wax" }\end{array}$ & $\begin{array}{l}\text { Decomposition } \\
\text { rapid; basically } \\
\text { the same; no } \\
\text { flame }\end{array}$ \\
\hline
\end{tabular}

(a) At $50^{\circ} \mathrm{C}$ and $80^{\circ} \mathrm{C}$ no change occurred for any waste type. At $150^{\circ} \mathrm{C}$ the melting and softening of the polyvinyl chloride and polyethylene wastes were the only changes observed. 
TABLE VI

PLUTONIUM IN SOLUTION AFTER LEACHING FROM SPIKED TASTES

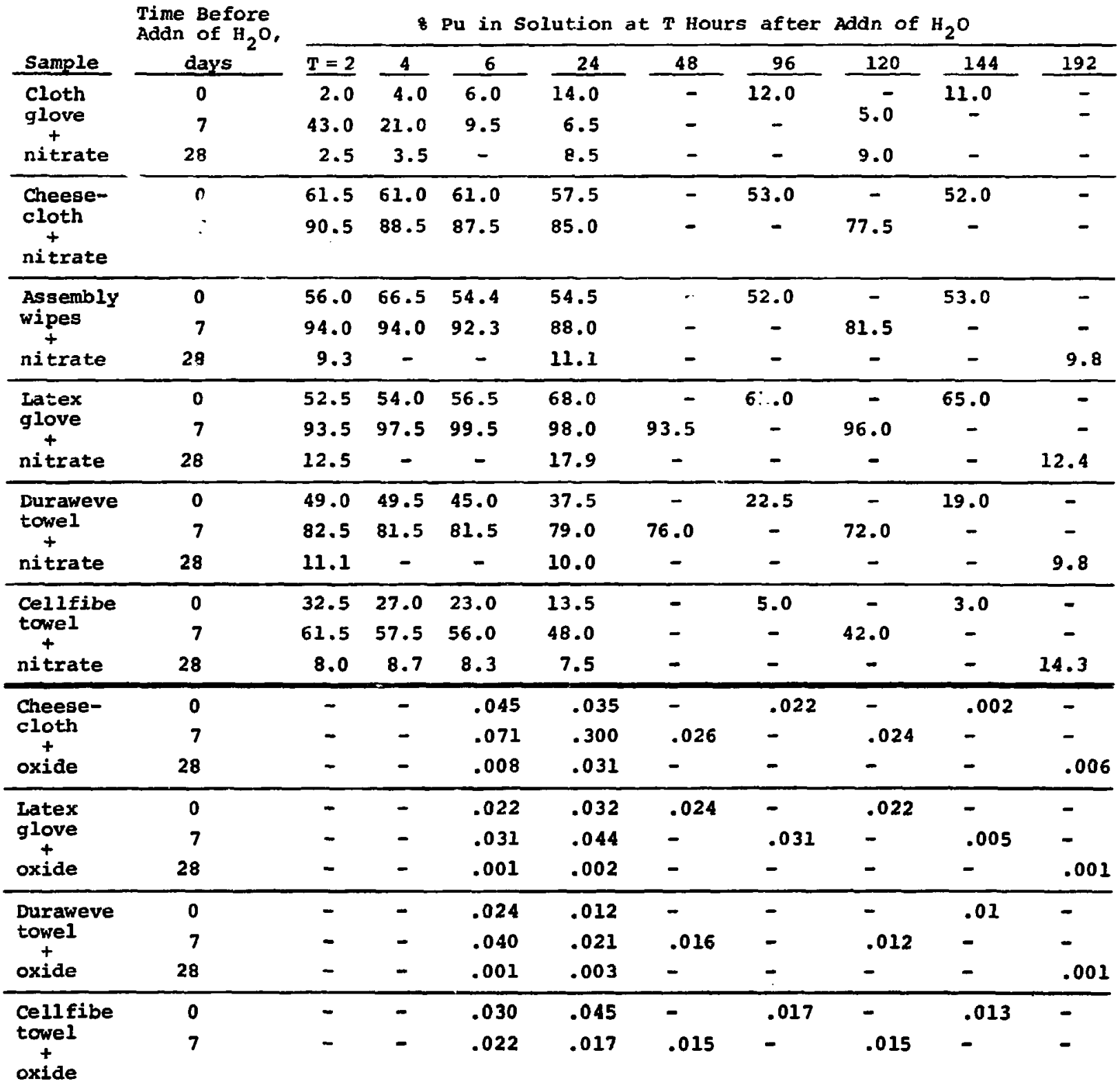

results obtained for wastes in this experiment. The greatest amount of plutonium leaching from the waste occurs in the first few hours of liquid contact. The relatively rapid rise in the quantity of plutonium in solution and subsequent decline is probably due to the initial leaching of the material in a soluble form followed by polymerization and hydrolysis; the colloidal suspension thus produced was removed by filtration. In exception to the general results was abserved for the cloth glove which dieplayed anomalous behavior in both the nitrate and the oxide experiments. 
This difference in behavior may be due to the sulfonated liner of the glove which may complex the plutonium to produce a more tightly bound form. In addition, nitrate spiked samples that aged in air for seven days prior to addition of the liquid exhibited significant increases in the total amount of plutonium leached. One tentative theory explaining this behavior is that the nitxic acid in the spiking solutions may react with the waste materials to render them less able to hold the plutonium. Nitric acid is frequently present as a chemical contaminant on line-generated wastes. When the nitrate-spiked samples are permitted to age for 28 days before addition of the liquid, much of the nitrate appears to convert to the oxide form, thus decreasing the amount of plutonium leached.

The form of the plutonium in solution is important in assessing the possibility of migration in soils. The solutions from the leach tests described previously were filtered through $5 \mathrm{\mu m}$ micropore filters to remove the insoluble products of hydrolysis and polymerization. One portion of filtrate was analyzed for plutonium immediately; the remaining filtrate was divided into two portions. Ten milliliters of the filtrate was added to five grams each of a cation exchange resin ( $A G 50 \mathrm{~W}-X 8$ ) and an anion exchange resin (AG $1-X 4$ ).

After two hours, each mixture was filtered, and aliquots were analyzed for plutonium. The plutonium from the nitratespiked samples was 95 to 1008 removed from solution by the cation exchange resin, while the anion exchange resin did not remove any significant fraction of the plutonium. These aata indicate that the plutonium in solution is essentially cationic and should be held by soils with good cation exchange properties. Plutonium leached from the oxide-contaminated wasted was about 50 removed from solution by either anion or cation exchange resine. This situation is indicative of a surface phenomenon and suggests that the plutonium is present in hydrolyzed or polymerized form small enough to pass through the micropore filter.

VI. ION EXCHANGE FROM BRINE

As a part of the initial phases of the transuranic waste program concerning the possibility of a permanent repository in salt beds, studies were initiated to determine the effect of brine on the ion exchange properties of plutonium in solution. The effect of the presence of large quantities of brine was investigated by measuring the retention of $\mathrm{Pu}$ (III) and $\mathrm{Pu}(\mathrm{IV})$ on synthetic resins which might be considered as "ideal" exchangers. The results of this work were reported previously. ${ }^{l}$ with the addition of the following studies of $\mathrm{Pu}(\mathrm{VI})$ in brine solutions this work is now completed.

In the above tests, approximately $500 \mathrm{mg}$ of plutonium were dissolved in $\mathrm{ACi}$, and the oxidation state was adjusted by either ozonolysis for $\mathrm{Pu}(\mathrm{VI})$ or oxidation with $\mathrm{HNO}_{3}$ for $\mathrm{Pu}(\mathrm{IV})$. The $\mathrm{pH}$ was adjusted by evaporation of the solution and dissolution in a solution (either water or brine) of known pH. This solution was then slurried with weighed quantities of exchange resin for two hours. Aliquots were removed and analyzed for plutonium.

The results in Table VII show that for cation exchange resins (1) the presence of brine decreases the capacity of the resin

TALS VII

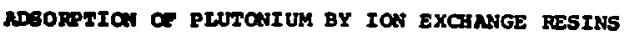
(ng Pu/g Exchanger)

\begin{tabular}{|c|c|c|c|c|c|}
\hline lolution & 24 & Bagin & Pu(III) & Pu(IV) & Pu(v) \\
\hline $\mathrm{I}_{2} \mathrm{O}$ & $\mathbf{0}$ & Cation, AG 50N-xo & 48.0 & 75.0 & 51.1 \\
\hline & $\mathbf{0}$ & Cation, AG 5ok-XB & 53.0 & 0.0 & 14.7 \\
\hline Brine & 7 & cation, at 50w-xB & 61.9 & 0.0 & 12.7 \\
\hline & $\mathbf{0}$ & anton, Ne 1-x4 & 0.0 & 4.9 & 19.6 \\
\hline Drtne & $\mathbf{0}$ & Anton, aG $1-x 4$ & 27.0 & 10.9 & 29.2 \\
\hline Brtno & 7 & Anton, se $1-x_{4}$ & 21.8 & 18.0 & 42.9 \\
\hline
\end{tabular}


for holding $\mathrm{Pu}(\mathrm{IV})$ and $\mathrm{Pu}(\mathrm{VI})$, (2) $\mathrm{Pu}(\mathrm{III})$ is removed to a slightly greater extent from solutions of saturated brine than from aqueous solutions, and (3) $\mathrm{Pu}(I V)$, the species most likely to be present in waste materials, is not held at all in the presence of brine. Conversely, the adsorption of plutonium by anion exchange resins is enhanced by the presence of the saturated brine solutions due to the formation of anionic complexes with the plutonium.

\section{MEASUREMENTS OF ACTIVITY IN WASTES}

Three general levels of radioactivity have been set as guidelines for waste handling. These categories are (1) less than $10 \mathrm{nCi} / \mathrm{g}$ of waste, which will go to controlled burial in the environment: (2) from $10 \mathrm{nCi} / \mathrm{g}$ to the lower limit for recovery, which will go to retrievable storage; and (3) above the recovery limit, which will be reprocessed. Although the material in the third category is not a waste, the residues from the recovery process are wastes which will fall into categories 1 or 2 .

The principal aipha emitters of interest are ${ }^{233} \mathrm{v}$, the plutonium isotopes 238 , 239, 240 and 242 , and ${ }^{241} \mathrm{Am}$. Assay instrumentation is needed to provide a "go - no go" response to facilitate sorting of the wastes into the three general categories.

Work on this program has centered on waste measurements at the $10 \mathrm{nCi} / \mathrm{g}$ level for low density wastes, such as rubber gloves and kimwipes. A thin NaI detector (1/16" thick $\times 5^{\prime \prime}$ aiameter) based on the FIDIER concept of J. Tinney ${ }^{3}$ at ILL, has been procured and is presently being set up to measure a flat array of solid, low density wastes to determine the detection sensitivities. Additionally, various radioactive standards of known activity and species have been produced in order to simulate wastes of known radioactive content. Calculations of the detectability of the FIDLER for various isotopes of uranium, plutonium, and americium in water have been made using the previous data of Tinney.
These calculated detectabilities are consistant with measurements made here using the FIDLER.

As an example of detectability limits obtainable with such a system, ${ }^{241}$ Am can be detected in water at the 0.04 MPC level, the present MPC level for public water systems being $4 \times 10^{-6} \mu \mathrm{Ci}{ }^{241} \mathrm{Am} / \mathrm{cm}^{3}$. This detectability is obtained in a 200-second counting time at the $3 \sigma$ level above the background. The ${ }^{241}$ Am detectability limit in water of $0.04 \mathrm{MPC}$ is equivalent to $5 \mathrm{x}$ $10^{-8} \mathrm{ppm}$ or $5 \times 10^{-8} \mathrm{\mu g}{ }^{241} \mathrm{Am} / \mathrm{cm}^{3}$ water. For comparison, the $10 \mathrm{nCi} / \mathrm{g}$ level for transuranic waste storage is equivalent to $3 \times 10^{-3} \mathrm{ppm}$ or $3 \times 10^{-3} \mathrm{\mu g} 241$ Am/g waste. Such calculations underlie the present thrust toward a FIDLER-based detection system. For low density waste measurements with good geometry, such an assay system appears very promising. Accordingly, work is presently in progress to determine the detectability limits of the FIDLER for various waste forms and geometries.

\section{PROGRAY FOR THE NEXT PERIOD}

A major part of the effort for the next period will be devoted to the preparation of draft criteria covering the packaging, handling, and storage of solid transuranic wastes. The current goal is to have preliminary drafts available for external review at the end of the period.

The experimental program will continue the corrosion studies of the 17C drum, supplemented by the examination of packages of actual wastes recovered from burial and from retrievable storage. In addition, the radiolytic effects of alpha particles on. polyvinyl chloride and polyethylene will be studied.

The field test program will include the loading of typical wastes into instrumented test drums in order to study the effects of heat on the waste matrices. In addition, 55-gallon drums containing typical waste matrices will be placed in an underground test chamber for studies of com- 
bustion and corrosion under simulated storage conditions.

\section{ACKNOWIEDGEMENTS}

This report represents the joint efforts of a number of people. In Group $\mathrm{H}-7$ the program manager was Eric Fowler with Karen Pashman and John Warren as staff members working on the waste survey and the general coordination of data. In Group CMB-1 the analytical work and studies of corrosion, leaching, and ion exchange were under the direction of Glenn Waterbury and sue MacDougall; and in CMB-11 the field studies -lus assistance on the waste survey were under the direction of Eldon Christensen and
Ray Mulkin. The work in Group $A-1$ on measurements was performed by John Umbarger. Jack Healy of H-Division office provided supervision and advice on the preparation of this report.

\section{REFE RENCES}

1. Eric B. Fowler, compiler, "Transuranic Waste Repository Studies," Los Alamos Scientific Laboratory Report LA- S127-MS, Vol. I (December, 1972).

2. "Serious Accidents," Issue No. 293, USAEC (August 26, 1968).

3. Tinney and Koch, "Hazards Control Progress Report No. 29 (September-December 1967) and Index to Hazards Control Progress Reports. Nos. 27 through 29," Lawrence Livermore Laboratory Report UCRL $-50007-67-3$. 